\title{
Teachers' Attitudes towards English as a Foreign Language and Their Influence on Students' Attitudes and English Learning: A Qualitative Study
}

\author{
Dr Rola Ahmed Massri \\ University of Jeddah \\ Jeddah, Saudi Arabia
}

\begin{abstract}
This study, based on a qualitative research design, aimed at investigating English as a Foreign Language (EFL) teachers' attitudes towards teaching English as a foreign language (FL), and how they influence their students' attitude and progress in English language learning. The main investigation in this study is whether or not teachers' attitudes, negative and positive, have an effect on the students' motivation, and ultimately, English language acquisition, as some of the literature suggests. The participants were two groups. The first group were thirty-five preparatory year program (PYP) students at a major University in Saudi Arabia, and in the second group, five EFL teachers at the same university. The thematic analysis of the transcribed interviews generated a total of 16themes which were further developed and arranged under five main categories. Keywords from the interviews were extracted, and the codes and categories were applied. The data analysis revealed several positive inclinations towards learning English when the teachers follow a favourable pedagogical approach. The conclusions drawn are that when teachers have strong positive attitudes towards teaching English, students have positive attitudes where the teachers managed to influence the reluctant students' mindset to a more flexible one as well as providing motivation and willingness in the students to face the challenges of learning English. Some recommendations were made for future research.
\end{abstract}

Keywords: EFL, motivation, qualitative research, Saudi Arabia, thematic analysis.

\section{Introduction}

English is arguably the dominant language in academics and businesses in many parts of the world. Learning to speak and write English fluently is considered an essential skill. Many non-English speaking countries where the national language is not English, have exerted efforts to teach English from the school level onwards. These include countries in the Middle East, Asia, and Africa. Teachers, at such schools, are usually locals who have undertaken studies at the college level. As in other educational fields, the attitude of teachers goes a long way in motivating or de-motivating students(Abrar, Mukminin, Habibi, Asyrafi, \& Marzulina, 2018).

Gömleksiz (2010) is of the opinion that the age, socio-economic status, methods and strategies of teaching, the learning attitude, and expected benefits in learning, influence teachers' approaches and students' attitudes towards learning a foreign language. The social and business outlook in the community has a significant effect on teaching and learning. Students and teachers are a part of their community and culture. Mellom, Straubhaar, Balderas, Ariail, and Portes (2018) point out that when the culture, attitude of elders, business and employment opportunities support learning English, then teachers and students are motivated to gain proficiency. However, if the attitude in the community is sceptical of the benefits, then the learning of English becomes a chore and teachers try to complete the curriculum and students take minimal efforts to get a passing grade. As such, this study seeks to explore the teachers' and students' epistemological and cognitive competencies with regards to teaching and learning English.

\subsection{Research Question and Objectives}

This research study is guided by the primary question: "What are teachers' attitudes towards English as a Foreign Language and the influence on students' attitudes and English learning?"

The research is further guided by the following three secondary questions:

[1] What are the declared teachers' attitudes towards English as a foreign language and for teaching English?

[2] Is there a relationship between the teacher's and the student's attitudes?

[3] Is there a relationship between the teacher's attitude and student English learning?

\section{Literature Review}

Crystal (1997) defines attitude as the evaluative reaction to objects, behaviours, events, situations that are the result of individual beliefs and opinions. Al Hosni (2014) researched speaking difficulties of EFL students in Oman. The author carried out a qualitative study with semi-structured interviews as well as observations with teachers and students. The author reported that students and teachers faced three problems: the mother tongue use, linguistic difficulties and inhibition. 
Teachers' attitudes, beliefs and perceptions in teaching English the teaching methods and strategies, curriculum activities, assessment evaluation, play a significant role in the challenges that students face. Al-Jamal and Al-Jamal (2014) conducted a mixed-method study by administering a mixed-method study with 566 Jordan students and 66 interviews to understand ESL learning difficulties. The findings indicated that respondents had low proficiency in speaking, and the causal factors were classroom population, less time for study, and lower teachers' interactions with students. While the teachers were interested, the large classroom size made close interactions difficult, leading to a reduced attitude of teachers and students in English. Chaney and Burk (1998) argue that speaking in a foreign language is about developing and conveying meaning with verbal and non-verbal symbols in different contexts and expressing ideas, thoughts, and the ability to recognise and interpret different meanings. Four factors cause difficulties in learning and speaking, and these are inhibition, low participation, having nothing to say or not having any motivation to speak. Mother tongue use is a common problem for students of English as a Second Language (ESL), and it indicates that the speakers use the same pronunciation, dialect, tones, and mix words when speaking in English. This habit can create a problem, and it is difficult to correct, requiring long hours of practice, listening, and speaking with native speakers.

Onwuegbuzie, Bailey, and Daley (1999)argue that foreign language speaking anxiety (FLSA) is a major concern for students in non-native English-speaking countries in Asia. This is particularly true for countries where Islam is the national religion since most of the learning and curriculum, conversations and other interactions occur in Arabic or other related languages, and communications in English are limited. Students have to perform strange and complex intellectual, cognitive and functional tasks that are subject to the influence of peer and instructor effect, the atmosphere in the classroom, number of students and their level of intelligence, nature and type of course content and interaction, making short speeches, and instructor accent. These factors can be managed with the correct instructor attitude and a learning environment.

Horwitz, Horwitz, and Cope (1986) used previous research to develop the Foreign Language Classroom Anxiety Scale (FLCAS) that measures students and teachers' anxiety in learning and teaching English. Aida (1994), Ely (1986) and Gardner, Lalonde, Moorcroft, and Evers (1987) conducted research studies that linked the level of anxiety to teachers and students towards ESL. The authors conclude that six sources of foreign language anxiety (FLA) are personal and interpersonal anxieties and these include communication apprehension, self-confidence and self-esteem; teachers beliefs about teaching, beliefs of students about learning languages, classroom methods such as speeches in the class, conversations, participating in discussions, nature of instructor interactions such as humiliation by teachers when they point out mistakes, and testing.

Tóth (2011) argues that FLA tends to create a fear psychosis among teachers and students about the ability to pronounce English words correctly and the negative evaluation of teachers. As a result, learning English invokes a feeling of inferiority and a lowering of the values among peers. Arab and Middle East students have a problem since they have a different accent that is tuned to Arabic words. Liu (2009) points out that public conversations where the students are expected to speak in English in the classroom tend to cause anxiety and distress. Teachers' attitudes and approaches towards error correction goes a long way to help students overcome their timidity. Female learners are more prone to developing anxiety while speaking English. Teachers' attitudes and expectations towards second language (L2) proficiency, less fluency, reaction time, comprehension, quality of expression, and inaccuracies tend to influence learning efficiency. Kondo and Ying-Ling (2004) are of the opinion that the classroom environment influences the speed and quality of learning and has an impact on anxiety levels. A negative correlation is seen between anxiety, classroom performance and course grades.

Árva and Medgyes (2000) believe that a non-native speaker teachers (NNESTs) may not have the desired level of proficiency and as a result, the teaching behaviour and attitude, social and political status; ethnicity can influence the attitude of students. The author thinks that while native English speaker teachers (NESTs) and NNESTS are separate entities for factors such as language proficiency, background, ethnicity, teaching behaviour, socioeconomic status, this does not mean that the teaching quality, dedication and attitude are different and that one entity should find favour over another. It is essential to consider and accord their status as professionals. Canagarajah (1999) differs from this view and argues that NESTs are ideal teachers who have superior knowledge and proficiency of the language, and they are supposed to be competent in pronunciation and fluency. Cook (1999) disagrees with these views and argues that non-NESTs show more empathy, tolerance towards mistakes and take extra efforts in teaching English since they have been through the same problem.

Han, Tanriöver, and Sahan (2016) conducted a study to examine the attitudes of NESTs, Non-NESTs and students in different Turkish English language teaching (ELT) educational institutions towards English. The objective was to research the attitudes and impact of teaching provided by NESTs and non-NESTS on FLSA of students. The researchers administered a survey to 48 students to understand their attitudes about FLSA for classes conducted by NESTs and Non-NESTs, and some students were also interviewed. Out of these, 33 were male, and 15 were females. The instrument had 24 items related to students' attitudes and anxiety based on their communication and preparedness. 
Four teachers from the two groups were interviewed with open-ended questions to examine their attitudes about FLSA and students experience in learning. Inferential statistics such as the Wilcoxon Signed Rank Test and the Mann-Whitney U-test were applied to understand the attitude differences for FLSA and courses taught by NESTs and non-NESTs. The results showed that statistically small differences were seen in attitudes towards NESTs and non-NESTs with NESTs scoring for Mann-Whitney $U$-test as $U=54.500, p=.330$, and $p<0.05$. For non-NESTs, the scores were $U=51.500, p=.944$, and $p<0.05$. The results indicate that there was very little difference in the attitudes of students towards the two groups of teachers. The qualitative results showed that teachers' attitude towards students was strong, and they were motivated in their profession. The overall conclusion is that a positive attitude of teachers irrespective of their group drives interest and performance among the students.

Agudo (2018)discusses the various opinions regarding the use of cognitive methods and effective ones in language classrooms. The author argues that emotions lead to attitudes, and these are often irrational, subjective, temporary and hard to define and implement. However, positive efforts are a result of cognition and emotions and that these are interlinked in teaching and learning, and that unlike science teaching, emotion and empathy assume social and political overtones in learning and teaching languages. Barcelos and Ruohotie-Lyhty (2018) add to these varying opinions and suggest that individual differences in teachers lead to attitude formation and that these are defined by classroom behaviour, linguistic skills, attitudes and feelings. Mercer and Kostoulas (2018)contend that it is important to understand the psychology in applied linguistics and foreign language education, the experiences and emotions that lead to attitude formation. Teachers are the focus in foreign language learning, and the love, passion, motivation, self-efficacy, the commitment they show for their profession has a far-reaching impact on attitude formation among students. Petrides, Pérez-González, and Furnham (2007)address the importance of trait emotional intelligence where the teachers' attitudes are formed from the traits they show, and this is an affect-related variance. Barrett (2017) opposes the suggestions above. He argues that emotions are constructions and not reactions, and these are formed on experiences that could occur without self-awareness and developed in a moment leading to the formation of experiences. That emotion is not unitary but can vary in frequency and strength. Therefore, a person with emotional intelligence has a range of emotional concepts that provide for flexible, functional response to a situation. Therefore, a person can be surprised or shocked and dumbfounded with a given set of experiences.

Dewaele (2018) presents the findings from research which he conducted and where the objectives were to understand the relationship between trait EI and teachers' attitudes, trait EI factors, and influence of their attitudes on students attitudes towards ESL education. The researcher designed an instrument based on the Trait EI Questionnaire and sent invitations to ESL/ EFL teachers. There were513 teachers from 103 countries responded with average experience in the teaching of 15 years. Independent variables measured included Well-being, Emotionality and Self-control. Statistical analysis and Spearman rank correlation analysis was used, and the scores had a mean $=4.56, \mathrm{SD}=.60$, and EI trait scores ranging from 2.7 to 5.9. Kolmogorov Smirnov values for the tests showed a mean of 4.1 , average SD of 0.0 .72 and the average KS score of 0.38 . The authors conclude that teachers with a high EI trait score showed a stronger attitude; there was a strong and significant correlation between the EI traits and sociability, with the love of English playing a substantial factor in increasing the attitude towards teaching and students.

From the various research studies which were disused above, a number of findings can be addressed from various points including the fact that the attitude of teachers is formed by communication apprehension, self-confidence and self-esteem; teachers beliefs about teaching, beliefs of students about learning languages, classroom methods such as speeches in the class, conversations, participating in discussions, nature of instructor interactions such as humiliation by teachers when they point out mistakes, and testing. Furthermore, the negative attitudes cause fear and anxiety of learning, and this can result in low motivation and a fall in scores. Teachers' attitudes towards their students are formed due to a number of factors such as self-skills, socio-economic conditions, classroom size, the external and internal environment, importance given to English in the society and business environment, and the interest shown by students. Three main themes are developed for the research, and these are attitudes, the relationship between the teacher's and the student's attitudes and relationship between the teacher's attitude and student English learning.

\section{Methodology}

This study is informed by the paradigmatic constructivist stance and qualitative research design where semistructured interviews were utilised. The interviews were conducted in two phases. The first phase was conducted with35 PYP student participants, and in the second phase, interviews were conducted with 5 teachers, where five of the students' group were their current students. Interviews were conducted and transcribed verbatim in Arabic. However, excerpts included in the findings were translated into English.

\subsection{Semi-Structured Interviews Instrument Design}

Two sets of instruments were designed, one for the 35 PYP students and the other for the five teacher participants. These are presented as follows: 


\subsubsection{Instrument for Teachers:}

A 22-item interview questions' instrument was custom designed and administered to teachers. The instrument was administered to five teachers, and it has three sections. The instrument is presented in Appendix A1.

\subsubsection{Instrument for Students}

A 15-item was designed and administered to 35students. The instrument has two sections and is presented in Appendix A2.

\subsection{Thematic Analysis}

For responses of the five teachers, thematic analysis is used by developing various codes and categories. According to Mihas (2019), coding in qualitative research analysis refers to a short phrase or a keyword that refers to important, meaning capturing, summative, and reflects an evocative attribute the responses. Responses in this research are the ones given by the five teachers who participated in the study. However, it can also refer to visual data, transcripts, participant observation, field notes, literature review, documents, correspondence, and others. Stuckey (2015) is of the opinion that it may be necessary to use two or more cycles for developing codes. For the first stage, codes are created in the form of words or sentences, phrases to form themes. For the second cycle, codes are placed in the longer text with code reconfiguration, and these are called as code categories. The category indicates the main content.

Blair (2015) argues that codes are developed as per the interpretation of responses. They represent the outcome that the respondent may want to convey, but the code is not mentioned explicitly. As an example, words such as sour, sweet, spicy are coded to represent the feelings that a respondent wants to convey, and these are placed under the category of taste. Another example of codes is red, orange, green, blue, and these belong to the category 'colour'. Vaughn and Turner (2016) suggest coding a summarised version of the data where it does not reduce the data, and the first impressions and phrases are taken into consideration. These are refined to develop the categories that are later used in data analysis. Details of codes and categories are described in section 3.2.1 and 3.2.2.

\subsubsection{Developing the Codes and Themes}

The data analysis revealed the following developed codes:

1. Growth mindset: This code refers to the time, effort and patience needed to grow. For EFL students with a different mother tongue, learning will take time, and it can be achieved by a growth mindset

2. Fixed mindset: This code refers to the dedication and a fixed;goal-oriented thinking where the students have decided to learn EFL. It is possible that some students are gifted, and they learn the language easily while others with less talent need a fixed mindset to learn.

3. Oral proficiency: Certain people have a natural proficiency to speak language fast while others have less proficiency. In such cases, it is important to develop a fixed mindset and be determined to learn ESL.

4. Mindset changes: It may be necessary to change the mindset and believe that one can learn the language.

5. Effort attributions: Success or failure is based on the perceived effort attribution.

6. Attribution to teacher: Success of failure is blamed on the perceived attitude of the teacher. The teacher can change the teaching method to motivate students to learn.

7. Ability attribution: A student may have a perception the learning EFL may be beyond the ability and may decide to give up when results are not forthcoming.

8. Disappointment: Students start learning EFL, assuming that they can master the language and converse, communicate quickly. However, this is not always possible, leading to disappointment.

9. Out to self: Students tend to develop an ego and positive feelings that they will major in English and be valued by their peers.

10. Jealousy: Some students may become jealous when their friends master English and are able to converse adequately, while the student lags.

11. FLA anxiety: Students develop some level of anxiety and show inhibition that people will ridicule them when they speak in English in public.

12. Cultural attitude: Some students from conservative Islamic families may be averse to learning English since they do not like the values and lifestyles. However, these students may still study English reluctantly for academic and job opportunities.

13. Family background: Parents and other family members may not be able to speak English. In such cases, the family environment may have a negative impact of learning.

14. Personality hardiness. Students may take up learning EFL in spite of problems since they have a fixed mindset and believe that they have to learn to succeed.

15. Resilience. Learning may present language learning obstacles and setbacks, and these exert a negative influence on learning. Students learn to take the stress and remain positive and learn to overcome the barriers.

16. Learned helplessness. Students find ways to miss classes and avoid studying. They find ways to kill time and pass the exam with minimum passing grades. 


\subsubsection{Developing the Categories}

Codes developed in section 3.2.1 are arranged in the following categories.

\section{Category A. Language learning mindset}

1. Growth mindset

2. Fixed mindset

3. Oral proficiency

4. Mindset changes

\section{Category B. Attribution styles}

5. Effort attributions

6. Attribution to teacher

7. Ability attribution

\section{Category C. Vision}

8. Disappointment

9. Out to self

10. Jealousy

11. FLA anxiety

\section{Category D. Attitudinal dispositions}

12. Cultural attitude

13. Family background

\section{Category E. Coping mechanisms}

14. Personality hardiness

15. Resilience

16. Learned helplessness

\subsection{Data Analysis}

\subsubsection{Analysis of Interviews}

The codes, themes and categories developed in sections 3.2.1 and 3.2.2 were applied to the responses provided by the five teachers. For each question, the responses and the applicable codes, themes and their categories are given as follows. From the transcripts, key phrases are extracted and used in the analysis.

3.3.1.1. Personal Experience with English

Q1. How do you feel towards English?

\begin{tabular}{|l|l|}
\hline Phrases keywords from Responses & Codes, themes and categories \\
\hline $\begin{array}{l}\text { Difficult and challenging, needs strong and dedicated efforts, } \\
\text { learning needs an innate ability, helps to grow and gain success. }\end{array}$ & $\begin{array}{l}\text { Category A. Language learning mindset: } 1 . \\
\text { Growth mindset, 2. Fixed mindset } \\
\text { Category B. Attribution styles } \\
\text { 5. Effort attributions, 7. Ability attribution } \\
\text { Category E. Coping mechanisms } \\
\text { 15. Personality hardiness }\end{array}$ \\
&
\end{tabular}

Q2. Why did you choose to specialise in English?

\begin{tabular}{l|l|}
\hline Phrases keywords from Responses & Codes, themes and categories \\
\hline Helps to gain recognition, easy to find well-paying jobs, & $\begin{array}{l}\text { Category D. Attitudinal dispositions, 13. Cultural } \\
\text { allows mobility, helps to learn in foreign universities since I } \\
\text { attitude, 15. Family background } \\
\text { am a linguistic teacher, like the respect, we have a need for } \\
\text { Category B. Attribution styles, 6. Attribution to } \\
\text { teacher, 7. Ability attribution }\end{array}$ \\
\hline
\end{tabular}

Q3. Is it a language you like and teach or more? Describe? 
My family is well educated, and English is common, I like to help overcome anxiety, some students have resilience against learning ESL, I have oral proficiency and like to teach, I like to teach and help students overcome their fear
Category A. Language learning mindset, 3. Oral proficiency

Category B. Attribution styles, 7. Ability attribution

Category C. Vision, 12. FLA anxiety

Category D. Attitudinal dispositions, 15. Family background

Category E. Coping mechanisms, 17. Learned helplessness

Q4. How was your experience as a student?

\begin{tabular}{|c|c|}
\hline Phrases keywords from Responses & Codes, themes and categories \\
\hline $\begin{array}{l}\text { Had anxiety, felt that learning English was beyond my ability, I was } \\
\text { disappointed with my progress, the cultural attitude suppressed } \\
\text { English, my oral proficiency was less. }\end{array}$ & $\begin{array}{l}\text { Category A. Language learning mindset, 3. Oral } \\
\text { proficiency } \\
\text { Category C. Vision, 12. FLA anxiety, } 9 . \\
\text { Disappointment } \\
\text { Category E. Coping mechanisms, 17. Learned } \\
\text { helplessness }\end{array}$ \\
\hline
\end{tabular}

Q5. How was your best teacher? Try to remember and describe your feelings?

\section{Phrases keywords from Responses}

Motivated me to learn, spent efforts to help us learn and gain proficiency, helped to reduce anxiety, teacher helped me to gain courage to overcome barriers, encouraged us to ignore culture and religious barriers

\section{Codes, themes and categories}

Category A. Language learning mindset, 1. Growth mindset, 2. Fixed mindset

Category B. Attribution styles, 6. Attribution to teacher Category C. Vision, 12. FLA anxiety

Q6. How was your worst? Try to remember and describe your feelings?

Phrases keywords from Responses

I had anxiety and panic attacks; some students were jealous of my progress, I was disappointed with my initial progress, I felt that learning English was beyond my ability, it was difficult to overcome my inability
Codes, themes and categories

Category A. Language learning mindset, 3. Oral proficiency, 4. Mindset changes

Category C. Vision, 9. Disappointment, 11. Jealousy, 12. FLA anxiety

Category E. Coping mechanisms, 16. Resilience,

17. Learned helplessness
Q7. Who affected you the most?

Phrases keywords from Responses

My teacher played a very positive role, my parents supported me, the cultural and religious barriers were high, some students were jealous of my progress, teacher helped me to develop endurance and courage
Codes, themes and categories

Category A. Language learning mindset, 4. Mindset changes

Category B. Attribution styles, 6. Attribution to teacher

Category C. Vision, 11. Jealousy, 12. FLA anxiety

Category E. Coping mechanisms, 16. Resilience
Q8. What did you learn from them?

Phrases keywords from Responses

My teacher played a very positive role, my parents supported me, the cultural and religious barriers were high, some students were jealous of my progress, teacher helped me to develop fortitude and courage
Codes, themes and categories

Category A. Language learning mindset, 4. Mindset changes

Category B. Attribution styles, 6. Attribution to teacher

Category C. Vision, 11. Jealousy, 12. FLA anxiety

Category E. Coping mechanisms, 16. Resilience 
Q9. Do you think she affected you as a teacher yourself?

\begin{tabular}{|l|l|}
\hline Phrases keywords from Responses & Codes, themes and categories \\
\hline $\begin{array}{l}\text { She served a role model; I learnt to manage the anxiety of students, } \\
\text { helped me to develop proficiency, frequent conversations and } \\
\text { readings helped me to gain oral proficiency, helped me to change my } \\
\text { mind that I could not learn English. }\end{array}$ & $\begin{array}{l}\text { Category A. Language learning mindset, 1. Growth } \\
\text { mindset, 3. Oral proficiency, 4. Mindset changes } \\
\text { Category C. Vision, 12. FLA anxiety } \\
\text { Category E. Coping mechanisms, 15. Personality } \\
\text { hardiness }\end{array}$ \\
\hline
\end{tabular}

\subsubsection{Teaching English}

Q10. Why did you choose to teach English?

\begin{tabular}{|l|l|}
\hline Phrases keywords from Responses & Codes, themes and categories \\
\hline $\begin{array}{l}\text { Good career option and employability, motivated by my teacher who } \\
\begin{array}{l}\text { I respect, the respect I get from students and parents, helps me to } \\
\text { change students' mindsets, like to remove anxiety and help students }\end{array}\end{array}$ & $\begin{array}{l}\text { Category B. Attribution styles, 6. Attribution to } \\
\text { teacher, 7. Ability attribution } \\
\text { Category C. Vision, 9. Disappointment, 12. FLA } \\
\text { anxiety } \\
\text { Category E. Coping mechanisms, 16. Resilience }\end{array}$ \\
\hline
\end{tabular}

Q11. What are the positives you see in this job?

\begin{tabular}{|l|l|}
\hline Phrases keywords from Responses & Codes, themes and categories \\
\hline $\begin{array}{l}\text { Get respect and devotion from students, motivate students to learn and } \\
\text { grow, help them overcome anxieties and increase abilities, help them } \\
\text { develop proficiency, help them overcome religious and cultural } \\
\text { barriers }\end{array}$ & $\begin{array}{l}\text { Category A. Language learning mindset, 1. Growth } \\
\text { mindset, 3. Oral proficiency, 4. Mindset changes } \\
\text { Category B. Attribution styles, 6. Attribution to } \\
\text { teacher } \\
\text { Category C. Vision, 12. FLA anxiety, } \\
\text { Category D. Attitudinal dispositions } \\
\text { Category E. Coping mechanisms }\end{array}$ \\
\hline
\end{tabular}

Q12. What are the negatives?

\begin{tabular}{|l|l|}
\hline Phrases keywords from Responses & Codes, themes and categories \\
\hline $\begin{array}{l}\text { Difficult to change the mindset and make students believe, students } \\
\text { are disheartened when they cannot learn fast, difficult to overcome } \\
\text { religious and cultural barriers, some students are resistant and do not } \\
\text { want to learn, they have developed a negative mindset and personality. } \\
\text { Mindset changes } \\
\text { Category B. Attribution styles, 7. Ability } \\
\text { attribution } \\
\text { Category C. Vision, 9. Disappointment } \\
\text { Category D. Attitudinal dispositions } \\
\text { Category E. Coping mechanisms, 15. Personality } \\
\text { hardiness }\end{array}$ \\
\hline
\end{tabular}

Q13. What are your best moments in class?

Phrases keywords from Responses well in verbal and written work, when they thank me and look with respect, when manages to make them overcome the barriers, when I help them to cope with their problems
Codes, themes and categories

Category A. Language learning mindset, 3. Oral proficiency, 4. Mindset changes

Category B. Attribution styles, 5. Effort attributions, 7.

Ability attribution

Category D. Attitudinal dispositions

Category E. Coping mechanisms, 15. Personality hardiness

Q14. What are your worst?

Phrases keywords from Responses

Codes, themes and categories 
When students lose interest and the desire to learn, some students just about make the passing grade without gaining any proficiency, when some students become jealous and try to bring down a good performer, some students cannot overcome the mental and other barriers
Category A. Language learning mindset, 4. Mindset changes

Category B. Attribution styles, 7. Ability attribution

Category C. Vision, 9. Disappointment

Category D. Attitudinal dispositions

Category E. Coping mechanisms, 15. Personality hardiness

Q15. How do you overcome your worst moments?

\begin{tabular}{|l|l|}
\hline Phrases keywords from Responses & Codes, themes and categories \\
\hline $\begin{array}{l}\text { Understand and recall my position years back, encourage to overcome } \\
\text { anxieties, help to address barriers, develop a growth mindset, } \\
\text { encourage verbal proficiency }\end{array}$ & $\begin{array}{l}\text { Category A. Language learning mindset, 1. } \\
\text { Growth mindset } \\
\text { Category B. Attribution styles, 6. Attribution to } \\
\text { teacher, 7. Ability attribution } \\
\text { Category C. Vision, 12. FLA anxiety }\end{array}$ \\
\hline
\end{tabular}

Q16. What is the method you follow in class to motivate students?

Phrases keywords from Responses cultural and religious barriers, develop mindset changes, help students to develop personality hardiness.
Codes, themes and categories

Category A. Language learning mindset, 1. Growth mindset, 2. Fixed mindset, 3. Oral proficiency, 4. Mindset changes

Category C. Vision, 12. FLA anxiety

Category D. Attitudinal dispositions

Category E. Coping mechanisms

Q17. Do you think you are affecting them? In what way?

\begin{tabular}{|l|l|}
\hline Phrases keywords from Responses & Codes, themes and categories \\
\hline $\begin{array}{l}\text { There is a fear of failing and getting ridiculed; students feel that } \\
\text { learning English will not help them, culture and religious } \\
\text { barriers, lack of skilled teachers who motivate, a wrong mindset } \\
\text { that acts as a barrier so help them to cope }\end{array}$ & $\begin{array}{l}\text { Category A. Language learning mindset, 4. } \\
\text { Category B. Attribution styles, 6. Attribution } \\
\text { to teacher } \\
\text { Category C. Vision, 12. FLA anxiety } \\
\text { Category D. Attitudinal dispositions } \\
\text { Category E. Coping mechanisms }\end{array}$ \\
\hline
\end{tabular}

3.3.1.3 Teaching Development

Q18. What is the method you follow to develop yourself?

\begin{tabular}{|c|c|}
\hline Phrases keywords from Responses & Codes, themes and categories \\
\hline $\begin{array}{l}\text { Take up advanced courses, go on studies to British colleges, } \\
\text { learn about attributions and students psychology, learn about } \\
\text { barriers and methods to overcome them, learn to manage barriers } \\
\text { and about coping mechanisms }\end{array}$ & $\begin{array}{l}\text { Category A. Language learning mindset } \\
\text { Category B. Attribution styles } \\
\text { Category D. Attitudinal dispositions } \\
\text { Category E. Coping mechanisms }\end{array}$ \\
\hline
\end{tabular}

Q19. In what way development affects your students directly? Phrases keywords from Responses

I am able to understand their problems and heal the barriers, psychological and other barriers solution helps to overcome the problems, learning different methods helps to develop better teaching and curriculum, helps to understand and overcome attitudinal barriers, helps to develop a growth mindset
Codes, themes and categories

Category A. Language learning mindset, 1. Growth mindset, 4. Mindset changes

Category B. Attribution styles, 5. Effort attributions, 6. Attribution to teacher

Category D. Attitudinal dispositions

Category E. Coping mechanisms

Q20. What is the single point or points that you wish to change to the better in your teaching? 


\begin{tabular}{|l|l|}
\hline Phrases keywords from Responses & Codes, themes and categories \\
\hline $\begin{array}{l}\text { I wish to reduce class size so that better interactions are possible; it is } \\
\text { better to counsel failing students, give focus on the 3rs rather than } \\
\text { rote learning, have to increase coping mechanisms, help students to } \\
\text { overcome various barriers. }\end{array}$ & $\begin{array}{l}\text { Category A. Language learning mindset, 3. Oral } \\
\text { proficiency, 4. Mindset changes } \\
\text { Category B. Attribution styles, 7. Ability } \\
\text { attribution } \\
\text { Category D. Attitudinal dispositions } \\
\text { Category E. Coping mechanisms }\end{array}$ \\
\hline
\end{tabular}

Q21. Do you consider yourself an inspiration to your students? How?

\begin{tabular}{|l|l|}
\hline Phrases keywords from Responses & Codes, themes and categories \\
\hline $\begin{array}{l}\text { I think so since they treat me with respect, many come to me with } \\
\text { difficulties and listen, they listen carefully to what I say. They are } \\
\text { glad when they understand my explanations; many try their best to } \\
\text { converse in English, I encourage them and do not ridicule their } \\
\text { mistakes. }\end{array}$ & $\begin{array}{l}\text { Category A. Language learning mindset, } 4 . \\
\text { Cattribution B. Attribution styles, 7. Ability } \\
\text { Category D. Attitudinal dispositions } \\
\text { Category E. Coping mechanisms }\end{array}$ \\
\hline
\end{tabular}

Q22. If you have another option, do you continue in this profession? Why?

\begin{tabular}{|l|l|}
\hline Phrases keywords from Responses & Codes, themes and categories \\
\hline $\begin{array}{l}\text { I would like to continue as a teacher and teach at higher } \\
\text { universities, I would ask for position teaching pre-primary } \\
\text { schools and university students, teaching is the best } \\
\text { profession since I am helping my community, }\end{array}$ & $\begin{array}{l}\text { Category B. Attribution styles, 6. Attribution to teacher } \\
\text { Category D. Attitudinal dispositions } \\
\text { Category E. Coping mechanisms }\end{array}$ \\
\hline
\end{tabular}

3.3.2 Students Interview Response Analysis

Responses to interview questions were analysed for the 15 questions. A brief summary of the responses and analysis is given as follows.

Experience with English in school: Some of the responses to the questions in this section are: "My best teacher was the English teacher." "My teacher helped me to overcome my fears and anxiety." "I felt uncomfortable learning English, but my teacher helped me to develop proficiency."

Current Experience with English: "My current teacher takes efforts to help us develop proficiency." "On a scale of 10, I would rate 10 for her liking teaching English, since she gives individual attention to us." "My teacher encourages us to speak small sentences and corrects our mistakes without shaming us." "My teachers' attitude is positively influencing my learning."

\section{Findings and Discussion}

In the aforementioned sections where the findings from the interviews conducted with the teachers and from the interviews conducted with the students, are presented. This section discusses the findings where it answers the research objectives framed in section 1.1

\subsection{Attitudes}

The findings in section 3.3.1, where responses of teacher's interviews and section 3.3.3 where responses of students are analysed, bring out some important points. From the codes and themes developed in section 3.2, it is clear that teachers have positive attitudes towards teaching English and in continuing to be a teacher. It is clear from the themes and codes that teachers help in developing a learning mindset; they try to increase the ability of students and help them to overcome FLA anxiety. Teachers also understand the attitudinal dispositions and various barriers such as cultural, religious and family, and help the students to overcome them. One area where the teachers further help is in developing coping mechanisms to develop personality hardiness, resilience, and overcome learned helplessness. From the teachers' responses to questions under Teaching English, it is clear that students have a positive attitude towards English and their students. Teachers motivate the students to learn and develop proficiency with a growth mindset. All the teachers who were interviewed had positive attitudes towards English as a foreign language. 
They expressed their contention that this positive attitude which was the result of several factors such as early exposure to language through private schools, media, travelling abroad, and family influence and support, was the reason behind choosing a career in English teaching. Therefore, those teachers have strong positive attitudes towards teaching English.

\subsection{Relationship between the teacher's and the student's attitudes}

Findings from the students'interviews need to be considered with the teachers' interview findings in section 3.3.1, where the teachers' attitudes towards English, teaching and towards students are positive. This positive attitude created a positive influence on students, and they have a positive attitude towards learning and towards their teachers. The students are motivated by the teachers; they consider them with regards and as model figures. Therefore, the findings indicate the presence of a positive relationship between the teachers and their students' attitudes. Most of the students expressed that their attitudes are positively influenced by their teachers during the course.

\subsection{Relationship between the Teachers'Attitudesand Student' English Language Learning}

From the responses analysed in sections 3.3.1 and 3.3.2, it is clear that teachers have a positive attitude towards teaching English, and they motivate their students, help to overcome barriers and develop proficiency. These positive attitudes have helped students to overcome anxiety, develop a growth mindset and coping mechanisms. The findings of the study indicate the presence of a relationship between the teachers' attitude and their students' motivation towards learning English. Many students highlighted the role their teachers played in motivating them to work hard, and some of them even expressed how did their teacher change their mindset to a more flexible one as well as willing to face the challenges of learning English.

\section{Recommendations for Further Research}

This research study intended to make several contributions in the field of understanding the impact of teachers attitudes on students' attitudes towards teaching and learning English. Some further studies are required to explore the overall improvement in exam grades and scores using an empirical study. Another suggestion is to increase the participating sample to cover a larger number of students and teacher participants.

\section{References}

Abrar, M., Mukminin, A., Habibi, A., Asyrafi, F., \& Marzulina, L. (2018). " If our English isn't a language, what is it?" Indonesian EFL Student Teachers' Challenges Speaking English. Qualitative Report, 23(1).

Agudo, J. (2018). Emotions in second language teaching. Theory, research and teacher education.

Aida, Y. (1994). Examination of Horwitz, Horwitz, and Cope's construct of foreign language anxiety: The case of students of Japanese. The modern language journal, 78(2), 155-168.

Al-Jamal, D. A., \& Al-Jamal, G. A. (2014). An Investigation of the Difficulties Faced by EFL Undergraduates in Speaking Skills. English Language Teaching, 7(1), 19-27.

Al Hosni, S. (2014). Speaking difficulties encountered by young EFL learners. International Journal on Studies in English Language and Literature (IJSELL), 2(6), 22-30.

Árva, V., \& Medgyes, P. (2000). Native and non-native teachers in the classroom. System, 28(3), 355-372.

Barcelos, A. M. F., \& Ruohotie-Lyhty, M. (2018). Teachers' emotions and beliefs in second language teaching: Implications for teacher education. In Emotions in Second Language Teaching (pp. 109-124): Springer.

Barrett, L. F. (2017). How emotions are made: The secret life of the brain: Houghton Mifflin Harcourt.

Blair, E. (2015). A reflexive exploration of two qualitative data coding techniques. Journal of Methods and Measurement in the Social Sciences, 6(1), 14-29.

Canagarajah, A. S. (1999). Interrogating the "native speaker fallacy": Non-linguistic roots, non-pedagogical results. Non-native educators in English language teaching, 7792.

Chaney, A. L., \& Burk, T. L. (1998). Teaching Oral Communication in Grades K-8: ERIC.

Cook, V. (1999). Going beyond the native speaker in language teaching. TESOL Quarterly, 33(2), 185-209.

Crystal, D. (1997). A dictionary of linguistics and phonetics: Blackwell Pub.

Dewaele, J.-M. (2018). The relationship between trait emotional intelligence and experienced ESL/EFL teachers' love of English, attitudes towards their students and institution, self-reported classroom practices, enjoyment and creativity. Chinese Journal of Applied Linguistics, 41(4), 468-487.

Ely, C. M. (1986). An analysis of discomfort, risktaking, sociability, and motivation in the L2 classroom. Language learning, 36(1), 1-25.

Gardner, R. C., Lalonde, R. N., Moorcroft, R., \& Evers, F. T. (1987). Second language attrition: The role of motivation and use. Journal of Language and Social Psychology, 6(1), 29-47.

Gömleksiz, M. N. (2010). An evaluation of students' attitudes toward English language learning in terms of several variables. Procedia-Social and Behavioral Sciences, 9, 913-918. 
Han, T., Tanriöver, A. S., \& Sahan, Ö. (2016). EFL Students' and Teachers' Attitudes toward Foreign Language Speaking Anxiety: A Look at NESTs and Non-NESTs. International Education Studies, 9(3), 1-11.

Horwitz, E. K., Horwitz, M. B., \& Cope, J. (1986). Foreign language classroom anxiety. The modern language journal, 70(2), 125-132.

Kondo, D. S., \& Ying-Ling, Y. (2004). Strategies for coping with language anxiety: The case of students of English in Japan. ELT Journal, 58(3), 258-265.

Liu, M. (2009). Reticence and anxiety in oral English lessons: Peter Lang.

Mellom, P. J., Straubhaar, R., Balderas, C., Ariail, M., \& Portes, P. R. (2018). "They come with nothing:" How professional development in a culturally responsive pedagogy shapes teacher attitudes towards Latino/English language learners. Teaching and Teacher Education, 71, 98-107.

Mercer, S., \& Kostoulas, A. (2018). Language teacher psychology: Multilingual Matters.

Mihas, P. (2019). QUALITATIVE ANALYSIS. Research Design and Methods: An Applied Guide for the ScholarPractitioner, 99.

Onwuegbuzie, A. J., Bailey, P., \& Daley, C. E. (1999). Factors associated with foreign language anxiety. Applied Psycholinguistics, 20(2), 217-239.

Petrides, K. V., Pérez-González, J. C., \& Furnham, A. (2007). On the criterion and incremental validity of trait emotional intelligence. Cognition and Emotion, 21(1), 26-55.

Stuckey, H. L. (2015). The second step in data analysis: Coding qualitative research data. Journal of Social Health and Diabetes, 3(01), 007-010.

Tóth, Z. (2011). Foreign language anxiety and advanced EFL learners: An interview study. WoPaLP, 5, 39-57.

Vaughn, P., \& Turner, C. (2016). Decoding via coding: Analysing qualitative text data through thematic coding and survey methodologies. Journal of Library Administration, 56(1), 41-51.

\section{Appendix A1}

\section{A1. Interview questions for teachers}

\section{Personal experience with English}

Q1. How do you feel towards English?

Q2. Why did you choose to specialise in English?

Q3. Is it a language you like and teach or more? Describe?

Q4. How was your experience as a student?

Q5. How was your best teacher? Try to remember and describe your feelings?

Q6. How was your worst? Try to remember and describe your feelings?

Q7. Who affected you the most?

Q8. What did you learn from them?

Q9. Do you think she affected you as a teacher yourself?

Teaching English

Q10. Why did you choose to teach English?

Q11. What are the positives you see in this job?

Q12. What are the negatives?

Q13. What are your best moments in class?

Q14. What are your worst?

Q15. How do you overcome your worst moments?

Q16. What is the method you follow in class to motivate students?

Q17. Do you think you are affecting them? In what way?

Teaching Development

Q18. What is the method you follow to develop yourself?

Q19. In what way development affects your students directly?

Q20. What is the single point or points that you wish to change to the better in your teaching?

Q21. Do you consider yourself an inspiration to your students? How?

Q22. If you have another option, do you continue in this profession? Why?

\section{Appendix A2}

\section{A2. Interview instrument for students}

\section{Experience with English in school}


Q1. How do you feel towards English?

Q2. When did you start feeling this way?

Q3. How was your best teacher in school?

Q4. How was your worst teacher in school?

Q5. Did they affect your feeling towards English in any way? How?

\section{Current Experience with English}

Q6. Does your feeling change in the foundation year? How?

Q7. How do you see your current teacher?

Q8. In a scale of 10, how much does she like English? Explain?

Q9. In a scale of 10, how much does she like teaching English? Explain?

Q10. Is she affecting your feeling towards English in any way? Positively? Negatively? How?

Q11. From your point of view, do you think the teachers' attitude is influencing your attitude towards English?

Q12. What is your favourite moment/s in class?

Q13. What is your worst moment/s in class?

Q14. How does your teacher motivate you in class?

Q15. Do you consider your teacher inspirational? 